\title{
pneumonia
}

Review

\section{Acute respiratory infection and bacteraemia as causes of non-malarial febrile illness in African children: a narrative review}

\author{
Florida Muro a Rita Reyburn ${ }^{b}$, Hugh Reyburn ${ }^{c}$

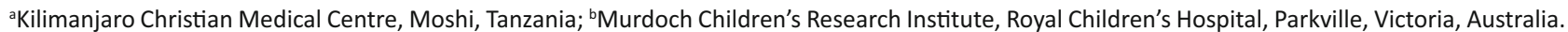 \\ Based at: New Vaccine Evaluation Project, Colonial War Memorial Hospital, Suva, Fiji; 'Department of Disease Control, London School of Hygiene and
} Tropical Medicine, UK

Corresponding author: Dr Hugh Reyburn, Department of Disease Control, London School of Hygiene and Tropical Medicine, Keppel St, London WICE7HT. Phone: +44 2079272881. Email: hugh.reyburn@Ishtm.ac.uk

Author contributions: All authors met ICMJE authorship criteria. FM and RR undertook literature searches and drafted the manuscript. RR extracted data from relevant publications. HR designed the paper, assisted with identifying publications and wrote the final version of the manuscript. All authors critically reviewed the manuscript for important intellectual content. All authors agreed with the manuscript results and conclusions.

Received 20 May 2014; Accepted 13 March 2015; Published May 292015

Citation: Muro F, Reyburn R, Reyburn H. Acute respiratory infection and bacteraemia as causes of non-malarial febrile illness in African children: a narrative review. pneumonia 2015;6:6-17

\begin{abstract}
The replacement of "presumptive treatment for malaria" by "test before treat" strategies for the management of febrile illness is raising awareness of the importance of knowing more about the causes of illness in children who are suspected to have malaria but return a negative parasitological test. The most common cause of non-malarial febrile illness (NMFI) in African children is respiratory tract infection. Whilst the bacterial causes of NMFI are well known, the increasing use of sensitive techniques such as polymerase chain reaction (PCR) tests is revealing large numbers of viruses that are potential respiratory pathogens. However, many of these organisms are commonly present in the respiratory tract of healthy children so causality and risk factors for pneumonia remain poorly understood. Infection with a combination of viral and bacterial pathogens is increasingly recognised as important in the pathogenesis of pneumonia. Similarly, blood stream infections with organisms typically grown by aerobic culture are well known but a growing number of organisms that can be identified only by PCR, viral culture, or serology are now recognised to be common pathogens in African children. The high mortality of hospitalised children on the first or second day of admission suggests that, unless results are rapidly available, diagnostic tests to identify specific causes of illness will still be of limited use in guiding the potentially life saving decisions relating to initial treatment of children admitted to district hospitals in Africa with severe febrile illness and a negative test for malaria. Malaria control and the introduction of vaccines against Haemophilus influenzae type $b$ and pneumococcal disease are contributing to improved child survival in Africa. However, increased parasitological testing for malaria is associated with increased use of antibiotics to which resistance is already high.
\end{abstract}

Keywords: Respiratory, infection, non-malaria, Africa, child 


\section{Introduction}

Interest in non-malarial febrile illness (NMFI) has increased following more widespread use of parasitological testing for malaria and, in particular, since 2010 when the World Health Organization (WHO) recommendation for antimalarial treatment for any unexplained fever was replaced by the recommendation that, wherever possible, antimalarial treatment should be restricted to children with a positive parasitological test $[1,2]$. Support for this policy by a number of major funders, including the Global Fund to Fight AIDS, Tuberculosis and Malaria, is having a major impact on case management of fevers in Africa. In the WHO Africa region, the number of rapid diagnostic tests (RDTs) for malaria that were distributed through national malaria control programmes rose from less than 2 million in 2006 to more than 80 million in 2012 [3]. Over the same period, the proportion of suspected malaria cases that received a diagnostic test rose from an estimated $20 \%$ to $60 \%$ [3]. Consequently, these developments are generating large numbers of patients who were previously treated for malaria but are now being considered for treatment of an alternative cause of fever [4].

The definition of NMFI is pragmatic but it remains a useful term in a period of transition from presumptive to more targeted treatment of febrile illness in African children. The term describes the situation of a patient with suspected malaria and a negative parasitological test. Like many causes of fever, malaria is an illness with clinical features that often overlap with other common causes of fever [5]. The most common of these is respiratory tract infection since fever can cause rapid breathing in children [6-8], and acidosis (commonly found in children with severe malaria) can cause deep laboured breathing with abnormal chest wall movement $[8,9]$. In addition, the features of cerebral malaria can be similar to those of meningitis [10], and fever without specific features can resemble non-severe malaria [11]. Diarrhoeal diseases rarely cause diagnostic confusion and so are not considered under NMFI. Similarly, otitis media or urinary tract infections usually present with clinical features that generally do not overlap with those of malaria. Low density Plasmodium parasitaemia may occur in the neonatal period but is usually asymptomatic due to the presence of maternal antibody and rarely meets our definition of NMFI [12]. Thus neonatal pneumonia, an important but specialised topic, is outside the scope of this review.

This review describes the main causes of NMFI in African children, with an emphasis on acute lower respiratory tract infections. Systematic testing of children for human immunodeficiency virus (HIV) is still not commonly practiced in Africa so there are few studies comparing causes of fever in children with or without HIV. The prevalence of HIV in hospitalised children varies between $1 \%$ and $17 \%$ in areas highly endemic for malaria but is considerably less in children presenting to outpatient clinics $[13,14]$. In this review, HIV-infected children have not been excluded and HIV data are shown where available.

\section{Diagnostic accuracy, overlapping definitions, and co- infection}

A definitive diagnosis of malaria is often difficult due to a number of reasons [15], the best known of which is that Plasmodium parasitaemia may be present as an incidental finding in a child with fever due to another cause. Determination of parasite density, which influences the attributable fraction of fever due to malaria, can be of help: The presence of parasites at high density make malaria more likely to be the cause of a child's illness than a low density infection, but this relationship is influenced by the level of malaria endemicity $[16,17]$. In addition, blood slide diagnosis may miss true $P$. falciparum infections due to either parasite sequestration or very low density parasitaemia, although true "slide-negative malaria" is probably rare. RDTs for malaria are not affected by parasite sequestration since they measure water-soluble parasite antigens but, in areas of high transmission, devices that detect histidine-rich protein-2 (HRP-2) may lack specificity due to the persistence of HRP-2 in blood for up to 6 weeks following infection $[18,19]$. Finally, up to $10 \%$ of children with severe malaria also have a blood stream bacterial infection, a fact that has led some to recommend antibacterial treatment of all children with severe malaria $[13,20]$. While some of these cases may be due to incidental parasitaemia, it is now well established that malaria itself is an important risk factor for non-typhi Salmonella (NTS) and other Gram-negative infections $[21,22]$.

\section{Pneumonia in African children}

Pneumonia is the most common alternative diagnosis to malaria in a febrile child in Africa $[8,9]$. The global incidence of hospital admissions of children with severe ALRI (including pneumonia and bronchiolitis) is agedependent: it is highest in children under the age of 2 years [23] and substantially higher in developing compared to industrialised countries, but similar between Asia and Africa $[23,24]$; however, hypoxaemia in children meeting WHO definitions of pneumonia severity [25] is more common in Asia [26] (possibly due to misclassification of children with malarial acidosis as severe pneumonia). Thirty-eight percent of childhood cases of severe ALRI do not reach hospital, and $81 \%$ of those severe ALRI cases result in death: substantially higher than in children hospitalised with severe ALRI [23]. This estimate was based on verbal autopsy and should therefore be treated with caution.

\subsection{Pneumonia case definitions}

The study of pneumonia suffers from, among other things, difficulties in obtaining a culture specimen from the site of infection and variation in case definitions [27], the former of which is currently being, at least to some extent, addressed by the study of Pneumonia Etiology Research for Child Health (PERCH)(Table 1) [33]. 
Table 1 Studies of pneumonia in children contributing to World Health Organization (WHO) clinical case definitions

\begin{tabular}{|c|c|c|c|c|c|}
\hline Study & Site & Sample size & $\begin{array}{l}\text { Gold standard } \\
\text { pneumonia } \\
\text { definition }\end{array}$ & $\begin{array}{l}\text { Clinical signs/symptoms } \\
\text { investigated }\end{array}$ & $\begin{array}{l}\text { Conclusions regarding } \\
\text { definition }\end{array}$ \\
\hline $\begin{array}{l}\text { Shann et al } \\
{[28]}\end{array}$ & $\begin{array}{l}\text { Goroka, } \\
\text { Papua New } \\
\text { Guinea }\end{array}$ & 350 & $\begin{array}{l}\text { Crepitations on } \\
\text { auscultation }\end{array}$ & $\begin{array}{l}\text { Age, RR, lower chest } \\
\text { wall indrawing, cyanosis, } \\
\text { wheeze, pulse rate, } \\
\text { palpable liver, } \\
\text { temperature }>37.5^{\circ} \mathrm{C}, \\
\text { feeds poorly }\end{array}$ & $\begin{array}{l}\text { RR }>50 / \text { minute was the } \\
\text { most accurate way to } \\
\text { differentiate pneumonia from } \\
\text { nonpneumonia }\end{array}$ \\
\hline $\begin{array}{l}\text { Cherian et al } \\
{[29]}\end{array}$ & $\begin{array}{l}\text { Vellore, } \\
\text { Tamil Nadu, } \\
\text { India }\end{array}$ & 682 & $\begin{array}{l}\text { Crepitations, } \\
\text { wheeze, bronchial } \\
\text { breathing or } \\
\text { radiological } \\
\text { abnormalities }\end{array}$ & $\begin{array}{l}\mathrm{RR} \text {, parental report of rapid } \\
\text { breathing, } \\
\text { intercostal retraction }\end{array}$ & $\begin{array}{l}\text { Refined the value of RR by } \\
\text { age stratification to }>50 \text { for } \\
\text { infants and }>40 \text { for children } \\
>12 \text { months }\end{array}$ \\
\hline $\begin{array}{l}\text { Campbell et al } \\
{[30]}\end{array}$ & $\begin{array}{l}\text { Banjul, } \\
\text { The Gambia }\end{array}$ & $\begin{array}{l}222 \\
\text { (episodes } \\
\text { of illness } \\
\text { in a cohort } \\
\text { study) }\end{array}$ & $\begin{array}{l}\text { Radiological } \\
\text { signs (lobar } \\
\text { consolidation) }\end{array}$ & $\begin{array}{l}\text { Vomiting, rapid breathing, } \\
\text { refusing to feed, chest } \\
\text { indrawing, RR, nasal flaring, } \\
\text { temperature, heart rate, } \\
\text { crepitations, bronchial } \\
\text { breathing or reduced air } \\
\text { entry, rhonchi, grunting }\end{array}$ & $\begin{array}{l}\text { Temperature }>38.5^{\circ} \mathrm{C} \text {, refusing } \\
\text { to feed and vomiting were } \\
\text { the most useful predictors of } \\
\text { severe pneumonia in infants, } \\
\text { whereas temperature }>38.5^{\circ} \mathrm{C} \\
\text { and } \mathrm{RR}>60 / \text { minute were the } \\
\text { most useful among children } \\
\text { aged } 1-4 \text { years old }\end{array}$ \\
\hline $\begin{array}{l}\text { Mulholland et } \\
\text { al [31] }\end{array}$ & $\begin{array}{l}\text { Philippines, } \\
\text { Swaziland }\end{array}$ & 730 & $\begin{array}{l}\text { Complete } \\
\text { history, physical } \\
\text { examination by } \\
\text { paediatrician, and } \\
\text { CXR }\end{array}$ & $\begin{array}{l}\text { Cough, difficulty breathing, } \\
\text { chest wall indrawing, } \\
\text { RR. Cases with wheeze } \\
\text { excluded }\end{array}$ & $\begin{array}{l}\text { Sensitivity and specificity } \\
\text { for RR }>40 / \text { minute or for } \\
\text { lower chest wall indrawing } \\
\text { were between } 0.77 \text { and } 0.81 \\
\text { in } 2 \text { different settings, but } \\
\text { specificity was lower when } \\
\text { judged by a healthcare worker }\end{array}$ \\
\hline $\begin{array}{l}\text { Simoes and } \\
\text { McGrath [32] }\end{array}$ & $\begin{array}{l}\text { Mbabane, } \\
\text { Swaziland }\end{array}$ & 362 & $\begin{array}{l}\text { Paediatrician's } \\
\text { assessment on } \\
\text { WHO criteria }\end{array}$ & $\begin{array}{l}\text { Cough, difficulty breathing, } \\
\text { ability to drink/feed well, } \\
\text { convulsions, abnormal } \\
\text { sleepiness, stridor, severe } \\
\text { undernutrition, fever, } \\
\text { wheeze, lower chest wall } \\
\text { indrawing, tachypnoea, } \\
\text { fever }\end{array}$ & $\begin{array}{l}\text { Using RR and lower chest wall } \\
\text { indrawing, nurses and nursing } \\
\text { assistants detected } 71 \%-83 \% \\
\text { of pneumonia cases with } \\
\text { specificity of } 84 \%-85 \%\end{array}$ \\
\hline
\end{tabular}

CXR, chest radiograph; RR, respiratory rate

Reproduced from Scott et al [33]

The selection of case definition depends on available diagnostic resources and priority for either high specificity (needed for clinical trials) or high sensitivity (needed for treatment of sick children) (Table 2). In most areas of Africa, the WHO definitions for severe pneumonia (cough and difficulty breathing with lower chest wall indrawing) and very severe pneumonia (cough and difficulty breathing with danger signs) [25] are generally followed, of which the definition of severe pneumonia is used most commonly. Raised respiratory rate (RR) or chest wall indrawing have a sensitivity and specificity of approximately $81 \%$ and $77 \%$, respectively, when compared to paediatrician diagnosis of pneumonia supported by chest roentgenogram [31]. In contrast to definitions of severe pneumonia, there is only one definition of the WHO category of "non-severe pneumonia" (cough or difficulty in breathing with raised
RR for age) but the significance of this as a risk factor for progression to severe pneumonia is not clear. While some studies have shown a correlation between raised $\mathrm{RR}$ and severe pneumonia [31,37], a placebo-controlled trial of amoxicillin in children with nonsevere pneumonia in Pakistan [38] failed to show a significant difference between trial arms, suggesting either that non-severe pneumonia may in the large majority of cases be due to a viral infection alone or the low specificity of the WHO definition of non-severe pneumonia includes many illnesses with a non-respiratory cause.

A number of studies, summarised by Rudan et al [24], have described predictors of mortality among African children with pneumonia that include malnutrition, HIV infection, subcostal recession, and altered consciousness. The latter 
Table 2 Examples of varying definitions of severe pneumonia depending on purpose

\begin{tabular}{|c|c|c|c|}
\hline Source & Very severe pneumonia & Severe pneumonia & Purpose \\
\hline WHO [25] & $\begin{array}{l}\mathrm{CDB}+\text { multiple convulsions or coma } \\
\text { or lethargy or vomiting everything or } \\
\text { inability to drink or cyanosis or severe } \\
\text { respiratory distress }\end{array}$ & $\mathrm{CDB}+$ chest indrawing & $\begin{array}{l}\text { Treatment of children with } \\
\text { suspected pneumonia }\end{array}$ \\
\hline Cutts et al [34] & & $\begin{array}{l}\text { Clinically suspected pneumonia } \\
\text { with radiological opaque or fluffy } \\
\text { opacities in part or all of a lobe of } \\
\text { the lung or pleural effusion }\end{array}$ & $\begin{array}{l}\text { Clinical trial of } \\
\text { pneumococcal vaccine }\end{array}$ \\
\hline Nokes et al [35] & As severe but $>2$ criteria needed & $\begin{array}{l}\mathrm{CDB}+>1 \text { of: intercostal indrawing, } \\
\text { inability to feed, increased RR for } \\
\text { age, } \mathrm{SPO}_{2}<90 \%\end{array}$ & $\begin{array}{l}\text { Epidemiological description } \\
\text { of admitted cases }\end{array}$ \\
\hline Scott et al [33] & $\begin{array}{l}\mathrm{CDB}+\text { any of: hypoxaemia }\left(\mathrm{SPO}_{2}<90 \%\right) \text {, } \\
\text { inability to feed, head nodding, or } \\
\text { impaired consciousness }\end{array}$ & $\mathrm{CDB}+$ chest indrawing & $\begin{array}{l}\text { Epidemiological description } \\
\text { of admitted cases }\end{array}$ \\
\hline Nair et al [23] & $\begin{array}{l}\text { As severe, + any IMCI danger sign or } \\
\text { hypoxaemia }\left(\mathrm{SPO}_{2}<90 \%\right)\end{array}$ & $\mathrm{CDB}+$ admitted to hospital & Estimation of global burden \\
\hline $\begin{array}{l}\text { Mulholland et al } \\
\text { [36] }\end{array}$ & $\begin{array}{l}\text { Invasive Hib disease verified by positive } \\
\text { isolate from blood or CSF culture }\end{array}$ & & $\begin{array}{l}\text { Randomised clinical trial of } \\
\text { Hib vaccine }\end{array}$ \\
\hline
\end{tabular}

$\mathrm{CDB}+$, cough/difficulty breathing plus; $\mathrm{IMCl}$, integrated management of childhood illnesses; $\mathrm{SpO}_{2}$, saturation of peripheral oxygen; RR, respiratory rate; Hib, Haemophilus influenzae type b; CSF, cerebral spinal fluid; WHO, World Health Organization

2 factors are reflected in the increased mortality associated with the WHO classification of "very severe" compared to "severe" pneumonia, respectively [39]. In addition, access to care is an important determinant of survival in children with pneumonia [23].

\subsection{Burden and causes of pneumonia in African children}

Estimating incidence and causes of pneumonia in Africa is difficult due to the problems already mentioned, compounded by the few high quality laboratories in Africa and the changing epidemiology created by vaccines and availability of polymerase chain reaction (PCR) methodologies. For more than a decade, the Child Health Epidemiology Reference Group (CHERG)-a group of independent technical experts on global child morbidity and mortality estimates co-sponsored by WHO and UNICEF-has grappled with these problems. The 2013 CHERG estimates are based on a model using estimates of prevalence of known risk factors, incidence data from control arms of pneumonia clinical trials [40], and results from 28 pneumonia incidence studies that met minimum inclusion criteria [41]. Even among these estimates, the incidence of pneumonia varied 100 -fold, reflecting both true variation but also lack of standardisation between studies. The CHERG estimates are summarised in Table 3. The 3 subsequent tables have been selected from published studies to illustrate specific issues with assigning causality to pneumonia in Africa, that is, the availability of PCR and the frequency of carriage of viral pathogens among healthy controls.

Table 4 is reproduced from a recent study in Malawi [42] demonstrating the range of pathogens commonly identified in African children admitted to hospital with severe pneumonia, albeit in an area of relatively high HIV prevalence. In addition, this study highlights the greatly increased sensitivity of PCR in detecting respiratory pathogens, although since the upper respiratory tract is not a "normally sterile site" the interpretation of the presence of these pathogens is challenging.

\subsubsection{Bacterial pneumonia}

The incidence of pneumonia due to Streptococcus pneumoniae or Haemophilus influenzae type $\mathrm{b}$ (Hib) is changing as vaccines against these infections are now being introduced across the continent. Currently, all African countries have introduced Hib conjugate vaccine in infants and all but 2 sub-Saharan African countries have introduced or are in the process of introducing infant vaccination using a 10 - or 13-valent pneumococcal conjugate vaccine (PCV-10 or PCV-13) [43].

The high efficacy of these vaccines in African children has been established in clinical trials $[34,36,44]$. The effectiveness of the Hib conjugate vaccine is encouraging, with reports of reductions to near-zero incidence of 
Table 3 Child Health Epidemiology Reference Group (CHERG) estimates of pneumonia in children 0-4 years of age in countries in the World Health Organization (WHO) Africa region shown as national level totals (incidence) and by causative pathogens; estimates of the number of new severe episodes (according to WHO's definition) in the year 2010 that require hospitalisations, shown as national level totals (severe episodes, all ALRI) and by causative pathogens; and estimates of the number of child deaths attributable to pneumonia in 2011 (mortality, all ALRI) and the proportion of deaths caused by causative pathogens.

\begin{tabular}{|c|c|c|c|}
\hline \multicolumn{4}{|l|}{ Population $0-4$ years $=134,240,762$} \\
\hline & Number of cases & Incidence/year & $\%$ of cases \\
\hline All ALRI & $36,412,108$ & $0.271(0.213-0.338)^{\mathrm{a}}$ & 100 \\
\hline \multicolumn{4}{|l|}{ Of which: } \\
\hline Streptococcus pneumoniae & $2,575,393$ & $0.019(0.015-0.022)$ & 7.1 \\
\hline Haemophilus influenzae type b & 780,756 & $0.006(0.003-0.006)$ & 2.1 \\
\hline Respiratory syncytial virus & $10,501,165$ & $0.078(0.061-0.090)$ & 28.8 \\
\hline Influenza virus & $6,215,546$ & $0.046(0.056-0.053)$ & 17.1 \\
\hline \multicolumn{4}{|l|}{ Other cause estimates not available } \\
\hline Severe ALRI (severe morbidity) & $4,166,781$ & $0.031(0.018-0.036)$ & 100 \\
\hline \multicolumn{4}{|l|}{ Of which: } \\
\hline Streptococcus pneumoniae & 761,241 & $0.006(0.004-0.007)$ & 18 \\
\hline Haemophilus influenzae type b & 130,134 & $0.001(0.0005-0.001)$ & 3 \\
\hline Respiratory syncytial virus & 558,669 & $0.004(0.003-0.005)$ & 13 \\
\hline Influenza virus & 171,931 & $0.001(0.001-0.002)$ & 4 \\
\hline \multicolumn{4}{|l|}{ Other cause estimates not available } \\
\hline ALRI Deaths (morbidity) & 531,451 & $0.004(0.002-0.005)$ & 100 \\
\hline \multicolumn{4}{|l|}{ Of which: } \\
\hline Streptococcus pneumoniae & 173,896 & $0.0013(0.001-0.002)$ & 33 \\
\hline Haemophilus influenzae type b & 42,404 & $0.0003(0.0001-0.0004)$ & 8 \\
\hline Other cause estimates not available & & & \\
\hline
\end{tabular}

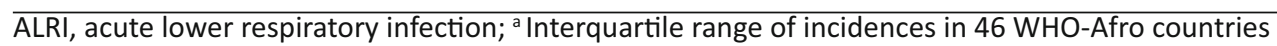

Adapted from Rudan et al [24]

invasive Hib disease following vaccination, although questions remain regarding the duration of protection following immunisation in infancy $[45,46]$.

The impact of PCV-10 is still being assessed and no large studies have so far been published. In a district hospital on the Kenyan coast, paediatric admissions for invasive pneumococcal disease (IPD) from the nearby demographic surveillance system have been continuously monitored since 2003 . There was a $50 \%$ reduction in admissions with IPD between 2003 and 2007 that may have been due to the reduction in malaria incidence that occurred between these years $[22,47]$. PCV-10 was first introduced to the childhood immunisation schedule in 2011. It is likely that PCV will bring additional benefits of secondary protection of older (unvaccinated) family members from IPD although there is also evidence of increased colonisation by nonvaccine strains of S. pneumoniae [46].

Staphylococcus aureus and Gram-negative infections are important, albeit in the minority, causes of bacterial pneumonia. Staphylococcal pneumonia is often very severe and may affect very young children. Nosocomial transmission of methicillin-resistant $S$. aureus is a particular problem in intensive care units and has been described in Ghana, although its routine detection in Africa is almost certainly hampered by lack of laboratory capacity [48]. Strains of S. aureus carrying the PantonValentine leukocidin genes cause a particularly severe form of pneumonia; while most reports of this organism are from developed countries, there is at least one case report of a fatal infection in a traveller returning from Senegal [49].

Gram-negative infections, and in particular NTS, are associated with malaria (as described below) and many of these qualify for the WHO definition of severe pneumonia. While this definition lacks specificity, there is clear evidence that these infections are responsible for true pneumonia defined by isolation of the organism from consolidated lung [50]. 
Table 4 Aetiology of radiologically confirmed pneumonia in Malawian children in 2011 using different laboratory methods

\begin{tabular}{|c|c|c|c|c|c|c|}
\hline & No. & HIV+ (\%) & $\begin{array}{l}\text { Blood } \\
\text { culture }\end{array}$ & $\begin{array}{l}\text { Lung aspirate } \\
\text { culture }\end{array}$ & $\begin{array}{l}\text { Lung aspirate } \\
\text { latex }\end{array}$ & $\begin{array}{l}\text { Lung aspirate } \\
\text { PCR }\end{array}$ \\
\hline \multicolumn{7}{|l|}{ Bacterial aeteology } \\
\hline Total & 45 & & 8 & 2 & 4 & 36 \\
\hline Streptococcus pneumoniae & 37 & 68 & 6 & 1 & 3 & 31 \\
\hline $\begin{array}{l}\text { Streptococcus pneumoniae / } \\
\text { Streptococcus typhimurium }\end{array}$ & 2 & 0 & 2 & 1 & 0 & NT \\
\hline Haemophilus influenzae type b & 6 & 67 & 0 & 0 & 1 & 5 \\
\hline \multicolumn{7}{|l|}{ Viral aeteology } \\
\hline Total & 24 & & NT & NT & NT & 24 \\
\hline Adenovirus & 15 & 53 & NT & NT & NT & 15 \\
\hline Bocavirus & 4 & 50 & NT & NT & NT & 4 \\
\hline Cytomegalovirus & 3 & 100 & NT & NT & NT & 3 \\
\hline \multicolumn{7}{|l|}{ Atypical } \\
\hline Chlamydia pneumoniae & 2 & 0 & NT & NT & NT & 2 \\
\hline Mycoplasma pneumoniae & 0 & & NT & NT & NT & 0 \\
\hline Pneumocystis jirovecii & 3 & 100 & NT & NT & NT & 3 \\
\hline
\end{tabular}

NT, not tested; PCP, pneumocystis pneumonia; Hib, Haemophilus influenzae type b; CMV, cytomegalovirus; HIV, human immunodeficiency virus; PCR, polymerase chain reaction

Bacteria: 2 patients had mixed infection with S. typhimurium and S. pneumoniae; 1 had S. typhimurium from blood culture and S. pneumoniae from blood PCR, and adenovirus from lung aspirate PCR, 1 had S. typhimurium from blood and lung aspirate culture and S. pneumoniae from lung aspirate PCR, 7 had S. pneumoniae/adenovirus, 1 had S. pneumoniae/chlamydia, 1 case with S. pneumoniae had Mycobacterium tuberculosis cultured from nasopharyngeal aspirate after induced sputum.

Pneumocystis: 1 patient had PCP/Hib, 1 patient had PCP/CMV, 1 patient had PCP/adenovirus

Viruses: 1 adenovirus/CMV, 1 adenovirus/chlamydia, 1 bocavirus/CMV

Reproduced from Carrol et al [42]

Table 5 Incidence of admission to a Kenyan district hospital with "severe pneumonia" or "very severe pneumonia" and viruses identified by polymerase chain reaction of nasal wash

\begin{tabular}{|c|c|c|c|c|c|c|c|}
\hline Age Group & under 28 days & $\begin{array}{l}\text { All } \\
<1 y\end{array}$ & $\begin{array}{l}1 \text { to } \\
1.99 y\end{array}$ & $\begin{array}{l}2 \text { to } \\
4.99 y\end{array}$ & $\begin{array}{l}\text { All } \\
<5 y\end{array}$ & $\begin{array}{l}5 \text { to } \\
12.99 \mathrm{y}\end{array}$ & $\begin{array}{l}\text { All } \\
<13 \text { y }\end{array}$ \\
\hline \multirow[t]{2}{*}{ Denominator } & 9,423 births & 8,837 & & & 44,538 & & 104,505 \\
\hline & per 1,000 live births & \multicolumn{6}{|c|}{ per 100,000 children/y } \\
\hline $\begin{array}{l}\text { 'Severe' or 'very severe' } \\
\text { pneumonia }\end{array}$ & 6.65 & 4,798 & 1,674 & 543 & 1,522 & 99 & 681 \\
\hline Any respiratory virus & 3.79 & 2,993 & 871 & 213 & 862 & 36 & 380 \\
\hline Respiratory syncytial virus & 2.46 & 2,038 & 455 & 85 & 535 & 15 & 233 \\
\hline Human coronavirus $229 \mathrm{E}$ & 0.51 & 318 & 135 & 32 & 105 & 3 & 46 \\
\hline Influenza A & 0.31 & 244 & 97 & 32 & 82 & 15 & 39 \\
\hline Human parainfluenza virus & 0.10 & 212 & 48 & 11 & 57 & 6 & 26 \\
\hline Adenovirus & 0.10 & 149 & 77 & 21 & 55 & 9 & 26 \\
\hline Human metapneumovirus & 0.20 & 138 & 58 & 11 & 44 & 6 & 21 \\
\hline
\end{tabular}

Reproduced from Berkley et al [51] 


\subsubsection{Viral pneumonia}

The study of viral pneumonia has been greatly enhanced by the use of PCR. A large case control study of paediatric hospital admissions for severe or very severe pneumonia (by WHO criteria) in Kenya in 2007 identified a number of viruses from a nasal wash specimen [51]. Consistent with other studies, the incidence of clinically diagnosed pneumonia was age-dependent, varying from $4.9 \%$ in the first year of life to $<0.1 \%$ in children over the age of 5 years (Table 5). Respiratory syncytial virus (RSV) was detected in almost half of the infants and a third of the children with severe or very severe pneumonia, followed in frequency by human coronavirus $(6.7 \%)$ and influenza virus type $A$ (5.8\%) while all others occurred at a frequency of less than $5 \%$. In addition, RSV was responsible for a strong seasonal trend in pneumonia incidence (Table 6). Among the viruses identified, only RSV was associated with severe disease (5\% in control participants; adjusted odds ratio, 6.11 [95\% $\mathrm{Cl}$ 1.65-22.6])

A number of case-control studies have documented that both viral and bacterial respiratory pathogens are frequently isolated from the upper respiratory tract of healthy children and this underlines the importance of including well-matched controls in any study of the causes of respiratory illness in children. RSV and influenza virus are most consistently found to be significantly associated with respiratory illness compared to controls, although the odds of association may not be strong enough to be diagnostically useful [51-54]. With regard to other viruses, it seems likely that factors such as co-infection and density of infection may need to be considered and the lack of association between cases and controls does not exclude a virus as a cause of pneumonia.

There is evidence from various sources of the association between viral and bacterial pneumonia. There are anecdotal reports of lobar pneumonia in association with the 1918 influenza pandemic and the H1N1 epidemic [55]. In a randomised, placebo-controlled trial of a 9-valent pneumococcal conjugate vaccine in South African infants, there was a $31 \%$ reduction in pneumonia associated with any of 7 respiratory viruses suggesting that infection with these viruses predisposes to pneumococcal pneumonia [56]. Immunological studies in mice suggest that infection with respiratory viruses impairs alveolar macrophage function for up to 10 days following infection and that this period was associated with severe and fatal bacterial pneumonia [57].

\subsubsection{Blood stream infections}

A study to identify bacterial causes of illness in subSaharan Africa identified 22 published studies since 1980 of children admitted to hospital with a blood culture result [58]. Overall, 5,364 (12.3\%) of 43,130 children had bloodstream infections. Of these, 1,643 (29.1\%) nonmalarial bloodstream infections were due to Salmonella enterica (of which $58.4 \%$ were due to NTS) and 1,031
(18.3\%) were due to $S$. pneumoniae. The commonly reported organisms isolated from febrile children in Africa include S. pneumoniae (18.3\%), NTS $(17 \%)$, S. aureus (9.5\%), and Escherichia coli (7.3\%).

The available evidence suggests that bacteraemia is uncommon in children with non-severe illness since the prevalence of a positive aerobic blood culture is approximately $1 \%$ compared to an incidence of up to $15 \%$ among children needing hospital admission [4,13,20,59].

As alluded to above, a number of studies have described $P$. falciparum infection as a risk factor for blood stream infection with NTS and other Gram-negative infections. This association was first investigated in The Gambia where it was observed that children with malaria whose fever did not settle on quinine treatment often grew NTS from their blood culture and these infections were limited to the malaria transmission season while carriage of NTS by domestic animals was perennial [60]. Studies from Kenya and Tanzania have since found a high risk of NTS infection in children with a positive HRP-2 rapid test for malaria but a negative blood film for Plasmodium parasites, suggesting that vulnerability to these infections may persist for several weeks after an episode of malaria $[13,20]$. The association and direction of causality of malaria has been strengthened further by the finding that the protection conferred by sickle cell trait (HbAS) against NTS is mediated by the protection against malaria associated with $\mathrm{HbAS}[22,61]$. Immunological studies have extended the understanding of possible mechanisms of how malaria reduces immune responses to NTS [62]. A recent comparison between areas of high and low malaria transmission has described a striking contrast in risk factors for NTS and S. typhi, the latter appearing to infect older, non-HIV-infected children $[63,64]$.

\subsubsection{Atypical infections}

In the context of this review, "atypical infection" is defined as infections not commonly isolated from aerobic blood culture. Knowledge of these infections in African children is limited, although increasing with the use of molecular diagnostics over the last decade. To investigate the frequency with which reports of these infections have been made, we used methods broadly the same as used by Reddy et al [58] and searched PubMed for reports of infection in Africa published between 1980 and 2014 of illness due to organisms not commonly isolated from blood culture. For practical reasons no age restriction was placed on the search, although papers that specifically referred to HIV-infected patients were excluded. A total of 389 reports met the inclusion criteria. The number of these reports for each infection provides only an approximate indication of incidence since the decision to report an infection depends on factors such as rarity, scientific interest, severity etc. However, evidence from a recent study in Tanzania suggests that some of these infections (e.g. leptospirosis, $\mathrm{Q}$ fever) may be relatively common, hence further studies including comparison with healthy controls and regional 


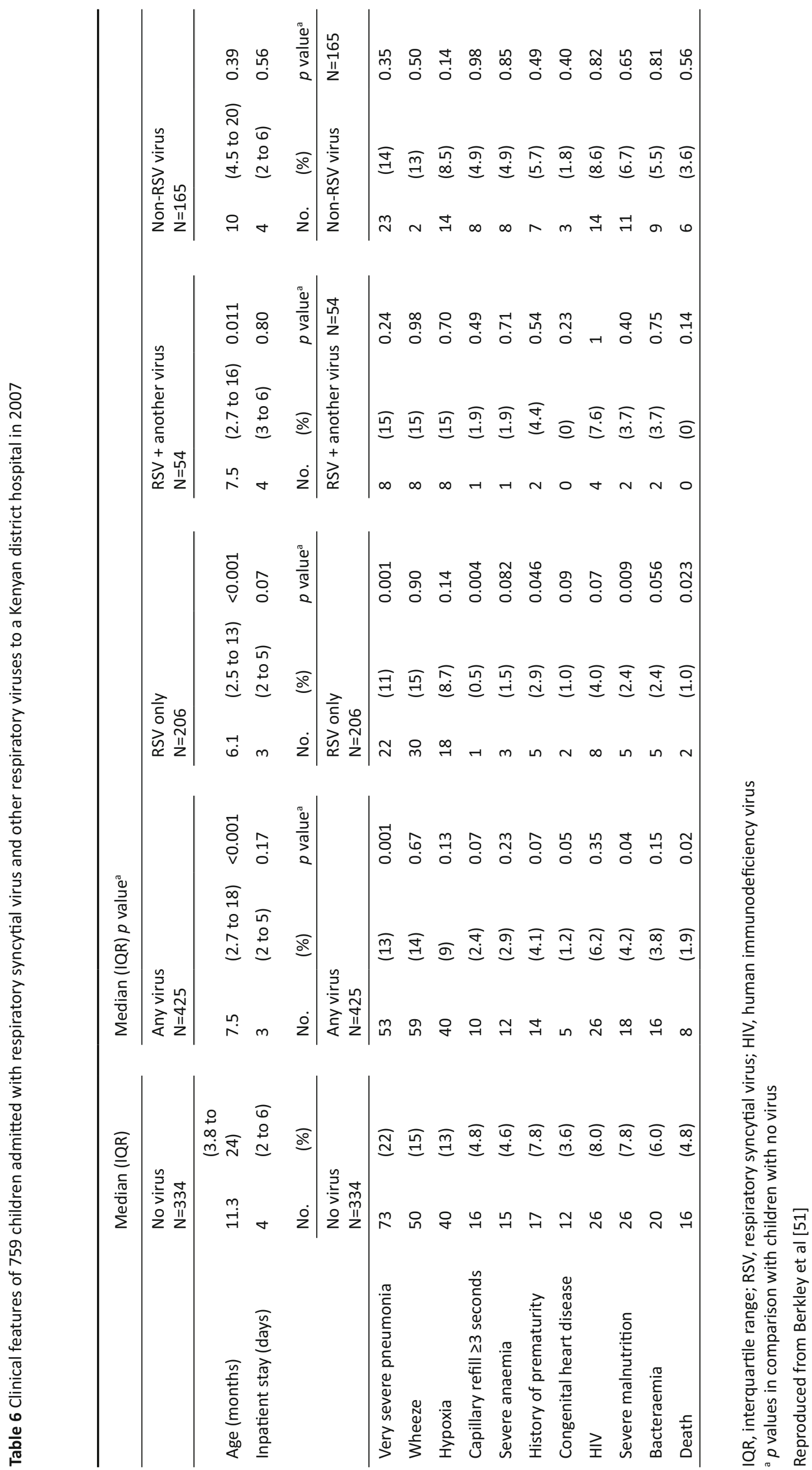


differences are indicated [65].

\section{Discussion}

The currently increasing attention to diseases that until now have been relatively neglected is encouraging, especially since a number of studies have shown that among hospitalised children with fever a negative malaria slide is generally associated with higher mortality. However, the recent attention to NMFI might lead some to think that a new epidemic has been discovered while in truth this is an "epidemic of awareness" of infections that have been present but neglected for a long time. In reality, the decline in malaria incidence has been associated with a reduction in invasive bacterial disease, particularly NTS infection. Falling incidence of malaria is by no means universal $[66,67]$. In many areas it is providing an opportunity to improve diagnostic accuracy and improved quality of care, but this process needs to be accompanied by improved surveillance of febrile illness and the antimicrobial susceptibilities of its causes.

\subsection{The usefulness of knowing the causes of NMFI}

There are a number of important reasons to know the local diagnostic probabilities of common causes of fever, the main one being the need for a guide to pragmatic treatment. However, there are very few effective interventions available for the treatment of sick children in African hospitals; the key treatment decision based on the likely pathogen is still limited to the use of an antibiotic and, if so, which one. More specific diagnostic information is usually limited to the results of a blood culture (not routinely available in most African hospitals and not available for the critical first 24-48 hours of admission).

Biomarkers to discriminate between blood stream bacterial compared to viral infection are still of limited clinical use. The reasons are that current tests that are available and affordable to most African hospitals lack sufficient sensitivity and specificity for routine use [42]. In non-severe illness, the proportion of children with a blood stream bacterial infection is approximately $1-3 \%[4,59]$ so that unless the specificity of a test is high, the predictive value of a positive test will be small and large numbers of antibiotic treatments will be given needlessly. In addition, a large number of tests with significant costs per test will be used to detect a small number of positives. By contrast, in children with severe illness the probability of a bacterial blood stream infection is relatively high and these infections are associated with significant mortality $[13,68]$. Thus, unless the sensitivity of the RDT is very high, a clinician would not be justified in withholding an antibiotic on the basis of a negative RDT for bacterial infection. The current WHO criteria for antibiotic treatment in severely ill children also suffer from lack of sensitivity and many clinicians would feel justified in prescribing antibiotics to all severely ill children, at least for the first 24-48 hours of admission, until blood culture results are known and during the period in which the majority of deaths in paediatric wards in Africa occur $[13,68,69]$. There is clearly a need to improve guidelines for care, particularly through incorporating quality-controlled laboratory results or "point of care" diagnostics into routine care.

\subsection{Disease surveillance and control}

There are additional public health reasons for a much more comprehensive knowledge of what infections are prevalent and where. These include the need to guide the deployment of vaccines or other preventive strategies. In addition, sentinel sites can identify emerging infections and, in particular, epidemic or pandemic threats to subSaharan Africa. This is increasingly important with growing global travel both into and out of the African continent.

\subsection{Future trends}

Child mortality is declining in Africa due to a number of reasons but the decline in malaria transmission intensity and the introduction of vaccines against Hib and pneumococcal disease are important contributors. There is an additional benefit to malaria control in that up to half of all blood stream bacterial infections in African children are caused by NTS and these infections become rare in children at low levels of malaria transmission, although may still be seen in HIV-infected adults [22,63]. This "added value" to malaria control could well account for the fact that malaria control has often been followed by greater than expected reductions in child mortality [70]. New vaccines, particularly against meningococcal disease and RSV are likely to have additional benefits to child survival in Africa.

These trends are very positive but one worrying effect of improvement in the diagnosis of malaria has been an increase in the prescription of antibiotics, which is likely to increase the already high levels of resistance to affordable antibiotics in Africa [13]. There is a need to more accurately define indications for antibiotic treatment in African children with non-severe illness and to review the use of amoxicillin in children with WHO criteria of "non-severe pneumonia", especially in a scenario where the incidence of bacterial pneumonia is declining.

\section{Acknowledgements}

The authors would like to acknowledge and thank Professor Brian Greenwood for critical review of the manuscript and advice and support in conducting the review.

Funding: FM was supported by Training Health Researchers into Vocational Excellence in East Africa (THRiVE); grant number 087540 funded by the Wellcome Trust. RR was supported by the Murdoch Children's Institute and HR was supported by the ACT Consortium of the London School of Hygiene and Tropical Medicine (LSHTM) from funds from the Bill and Melinda Gates Foundation (Grant code ITGBVG13). The funder had no role in the design of this review, compilation and interpretation of material, decision to publish, or preparation of the manuscript. 
Competing interests: All authors declare no competing interests.

Provenance and peer review: Not commissioned; externally peer reviewed.

Copyright: This is an open-access article distributed under the terms of the Creative Commons Attribution License, which permits unrestricted use, distribution, and reproduction in any medium, provided the original author and source are credited.

\section{References}

1. Whitty CJ, Leslie T, Chandler $\mathrm{Cl}$, Staedke SG. Management of malaria and other severe infections in rural Africa and Asia. BMJ. 2010;340:c1527. PMID:20237003 http://dx.doi. org/10.1136/bmj.c1527

2. World Health Organization. Guidelines for the diagnosis and treatment of malaria. $2^{\text {nd }}$ Ed. Geneva: WHO; 2010.

3. World Health Organization. World Malaria Report. Geneva: Global Malaria Programme of WHO. Geneva: WHO; 2013.

4. Mtove G, Hendriksen IC, Amos B, Mrema H, Mandia V, Manjurano $A$ et al. Treatment guided by rapid diagnostic tests for malaria in Tanzanian children: safety and alternative bacterial diagnoses. Malar J 2011;10:290.http:// dx.doi.org/10.1186/1475-2875-10-290 PMID:21978238

5. Chandramohan D, Jaffar S, Greenwood B. Use of clinical algorithms for diagnosing malaria. Trop Med Int Health 2002;7:45-52.http://dx.doi.org/10.1046/j.13653156.2002.00827.x PMID:11851954

6. Källander K, Nsungwa-Sabiiti J, Peterson S. Symptom overlap for malaria and pneumonia--policy implications for home management strategies. Acta Trop 2004;90:211-4. http://dx.doi.org/10.1016/j.actatropica.2003.11.013 PMID:15177148

7. O'Dempsey TJ, Laurence BE, McArdle TF, Todd JE, Lamont $A C$, Greenwood BM. The effect of temperature reduction on respiratory rate in febrile illnesses. Arch Dis Child 1993;68:492-5.http://dx.doi.org/10.1136/adc.68.4.492 PMID:8503674

8. O'Dempsey TJ, McArdle TF, Laurence BE, Lamont AC, Todd $J E$, Greenwood BM. Overlap in the clinical features of pneumonia and malaria in African children. Trans R Soc Trop Med Hyg 1993;87:662-5.http://dx.doi.org/10.1016/00359203(93)90279-Y PMID:8296367

9. English M, Punt J, Mwangi I, McHugh K, Marsh K. Clinical overlap between malaria and severe pneumonia in Africa children in hospital. Trans R Soc Trop Med Hyg 1996;90:65862.http://dx.doi.org/10.1016/S0035-9203(96)90423-X PMID:9015508

10. Berkley JA, Mwangi I, Mellington F, Mwarumba S, Marsh K. Cerebral malaria versus bacterial meningitis in children with impaired consciousness. QJM 1999;92:151-7.http:// dx.doi.org/10.1093/qjmed/92.3.151 PMID:10326074

11. d'Acremont V, Malila A, Swai N, Tillya R, Kahama-Maro $\mathrm{J}$, Lengeler $\mathrm{C}$ et al. Withholding antimalarials in febrile children who have a negative result for a rapid diagnostic test. Clin Infect Dis 2010;51:506-11.http://dx.doi. org/10.1086/655688 PMID:20642354

12. Wagner G, Koram K, McGuinness D, Bennett S, Nkrumah F, Riley E. High incidence of asymptomatic malara infections in a birth cohort of children less than one year of age in Ghana, detected by multicopy gene polymerase chain reaction. Am J Trop Med Hyg 1998;59:115-23. PMID:9684638

13. Nadjm B, Amos B, Mtove G, Ostermann J, Chonya S, Wangai $\mathrm{H}$ et al. WHO guidelines for antimicrobial treatment in children admitted to hospital in an area of intense Plasmodium falciparum transmission: prospective study. BMJ 2010;340:c1350.http://dx.doi.org/10.1136/bmj. C1350 PMID:20354024

14. Rogerson SR, Gladstone $M$, Callaghan $M$, Erhart L, Rogerson SJ, Borgstein E et al. HIV infection among paediatric in-patients in Blantyre, Malawi. Trans R Soc Trop Med Hyg2004;98:544-52.http://dx.doi.org/10.1016/j. trstmh.2003.12.011 PMID:15251404

15. Koram KA, Molyneux ME. When is "malaria" malaria? The different burdens of malaria infection, malaria disease, and malaria-like illnesses. Am J Trop Med Hyg 2007;77 Suppl:1-5. PMID:18165468

16. Bejon P, Mohammed S, Mwangi I, Atkinson SH, Osier $\mathrm{F}$, Peshu $\mathrm{N}$ et al. Fraction of all hospital admissions and deaths attributable to malnutrition among children in rural Kenya. Am J Clin Nutr 2008;88:1626-31.http://dx.doi. org/10.3945/ajcn.2008.26510 PMID:19064524

17. Chandler $\mathrm{Cl}$, Drakeley $\mathrm{CJ}$, Reyburn $\mathrm{H}$, Carneiro I. The effect of altitude on parasite density case definitions for malaria in northeastern Tanzania. Trop Med Int Health 2006;11:117884.http://dx.doi.org/10.1111/j.1365-3156.2006.01672.x PMID:16903881

18. Mtove G, Nadjm B, Amos B, Hendriksen IC, Muro F, Reyburn H. Use of an HRP2-based rapid diagnostic test to guide treatment of children admitted to hospital in a malaria-endemic area of north-east Tanzania. Trop Med Int Health 2011;16:545-50.http://dx.doi.org/10.1111/j.13653156.2011.02737.x PMID:21320243

19. Swarthout TD, Counihan H, Senga RK, van den Broek I. Paracheck-Pf accuracy and recently treated Plasmodium falciparum infections: is there a risk of over-diagnosis? Malar J 2007;6:58.http://dx.doi.org/10.1186/1475-28756-58 PMID:17506881

20. Berkley J, Mwarumba S, Bramham K, Lowe B, Marsh K. Bacteraemia complicating severe malaria in children. Trans R Soc Trop Med Hyg 1999;93:283-6.http://dx.doi. org/10.1016/S0035-9203(99)90024-X PMID:10492760

21. Mtove G, Amos B, Nadjm B, Hendriksen IC, Dondorp AM, Mwambuli A et al. Decreasing incidence of severe malaria and community-acquired bacteraemia among hospitalized children in Muheza, north-eastern Tanzania, 2006-2010. Malar J 2011;10:320.http://dx.doi.org/10.1186/14752875-10-320 PMID:22029477

22. Scott JA, Berkley JA, Mwangi I, Ochola L, Uyoga S, Macharia $A$ et al. Relation between falciparum malaria and bacteraemia in Kenyan children: a population-based, case-control study and a longitudinal study. Lancet 2011;378:1316-23.http://dx.doi.org/10.1016/S01406736(11)60888-X PMID:21903251

23. Nair H, Simões EA, Rudan I, Gessner BD, Azziz-Baumgartner E, Zhang JS et al.; Severe Acute Lower Respiratory Infections Working Group. Global and regional burden of hospital admissions for severe acute lower respiratory infections 
in young children in 2010: a systematic analysis. Lancet 2013;381:1380-90.http://dx.doi.org/10.1016/S01406736(12)61901-1 PMID:23369797

24. Rudan I, Boschi-Pinto C, Biloglav Z, Mulholland K, Campbell H. Epidemiology and etiology of childhood pneumonia [PubMed]. Bull World Health Organ 2008;86:408-16. http://dx.doi.org/10.2471/BLT.07.048769 PMID:18545744

25. Department of Child and Adolescent Health. Handbook: $\mathrm{IMCl}$ integrated management of childhood illness. World Health Organization; Geneva: 2005.

26. Subhi $R$, Adamson $M$, Campbell $H$, Weber $M$, Smith K, Duke T; Hypoxaemia in Developing Countries Study Group. The prevalence of hypoxaemia among ill children in developing countries: a systematic review. Lancet Infect Dis 2009;9:219-27.http://dx.doi.org/10.1016/S14733099(09)70071-4 PMID:19324294

27. Scott JA, Brooks WA, Peiris JS, Holtzman D, Mulholland EK. Pneumonia research to reduce childhood mortality in the developing world. J Clin Invest 2008;118:1291-300.http:// dx.doi.org/10.1172/JCI33947 PMID:18382741

28. Shann F. Clinical signs of pneumonia in children. Lancet 1988;2:792-3.http://dx.doi.org/10.1016/S01406736(88)92438-5 PMID:2901631

29. Cherian T, John TJ, Simoes E, Steinhoff MC, John M. Evaluation of simple clinical signs for the diagnosis of acute lower respiratory tract infection. Lancet 1988;2:125-8. http://dx.doi.org/10.1016/S0140-6736(88)90683-6 PMID:2899187

30. Campbell H, Byass P, Forgie IM, Lloyd-Evans N. Clinical signs of pneumonia in children. Lancet 1989;1:899-900. http://dx.doi.org/10.1016/S0140-6736(89)92890-0 PMID:2564973

31. Mulholland EK, Simoes EA, Costales MO, McGrath EJ, Manalac EM, Gove S. Standardized diagnosis of pneumonia in developing countries. Pediatr Infect Dis J 1992;11:77-81. http://dx.doi.org/10.1097/00006454-199202000-00004 PMID:1741202

32. Simoes EA, McGrath EJ. Recognition of pneumonia by primary health care workers in Swaziland with a simple clinical algorithm. Lancet 1992;340:1502-3.http://dx.doi. org/10.1016/0140-6736(92)92757-7 PMID:1361598

33. Scott JA, Wonodi C, Moïsi JC, Deloria-Knoll M, DeLuca AN, Karron RA et al.; Pneumonia Methods Working Group. The definition of pneumonia, the assessment of severity, and clinical standardization in the Pneumonia Etiology Research for Child Health study. Clin Infect Dis 2012;54 Suppl 2:S109-16.http://dx.doi.org/10.1093/cid/cir1065 PMID:22403224

34. Cutts FT, Zaman SM, Enwere G, Jaffar S, Levine OS, Okoko JB et al.; Gambian Pneumococcal Vaccine Trial Group. Efficacy of nine-valent pneumococcal conjugate vaccine against pneumonia and invasive pneumococcal disease in The Gambia: randomised, double-blind, placebo-controlled trial. Lancet 2005;365:1139-46.http://dx.doi.org/10.1016/ S0140-6736(05)71876-6 PMID:15794968

35. Nokes DJ, Okiro EA, Ngama M, Ochola R, White LJ, Scott $\mathrm{PD}$ et al. Respiratory syncytial virus infection and disease in infants and young children observed from birth in Kilifi District, Kenya. Clin Infect Dis 2008;46:50-7.http://dx.doi. org/10.1086/524019 PMID:18171213
36. Mulholland K, Hilton S, Adegbola R, Usen S, Oparaugo $A$, Omosigho $C$ et al. Randomised trial of Haemophilus influenzae type-b tetanus protein conjugate vaccine [corrected] for prevention of pneumonia and meningitis in Gambian infants. Lancet 1997;349:1191-7.http://dx.doi. org/10.1016/S0140-6736(96)09267-7 PMID:9130939

37. Shann F. Pneumonia in children in Papua New Guinea. P N G Med J 1987;30:143-9. PMID:3314244

38. Hazir T, Nisar YB, Abbasi S, Ashraf YP, Khurshid J, Tariq P et al. Comparison of oral amoxicillin with placebo for the treatment of world health organization-defined nonsevere pneumonia in children aged 2-59 months: a multicenter, double-blind, randomized, placebo-controlled trial in pakistan. Clin Infect Dis 2011;52:293-300.http://dx.doi. org/10.1093/cid/ciq142 PMID:21189270

39. Webb C, Ngama $M$, Ngatia $A$, Shebbe $M$, Morpeth $S$, Mwarumba $S$ et al. Treatment failure among Kenyan children with severe pneumonia--a cohort study. Pediatr Infect Dis J 2012;31:e152-7.http://dx.doi.org/10.1097/ INF.0b013e3182638012 PMID:22692700

40. Mulholland EK. Use of vaccine trials to estimate burden of disease. J Health Popul Nutr 2004;22:257-67. PMID:15609778

41. Rudan I, O'Brien KL, Nair H, Liu L, Theodoratou E, Qazi S et al.; Child Health Epidemiology Reference Group (CHERG). Epidemiology and etiology of childhood pneumonia in 2010: estimates of incidence, severe morbidity, mortality, underlying risk factors and causative pathogens for 192 countries. J Glob Health 2013;3:010401. PMID:23826505

42. Carrol ED, Mankhambo LA, Guiver M, Banda DL, Denis $B$, Dove $W$ et al.; IPD Study Group. PCR improves diagnostic yield from lung aspiration in Malawian children with radiologically confirmed pneumonia. PLOS ONE 2011;6:e21042. Epub 2011 Jun 14.http://dx.doi. org/10.1371/journal.pone.0021042 PMID:21695128

43. VIMS. (2014) Vaccine Information Management System (VIMS). In: Health JHBSoP, (IVAC) IVAC, editors.

44. Klugman KP, Madhi SA, Huebner RE, Kohberger R, Mbelle $\mathrm{N}$, Pierce N; Vaccine Trialists Group. A trial of a 9-valent pneumococcal conjugate vaccine in children with and those without HIV infection. N Engl J Med 2003;349:13418.http://dx.doi.org/10.1056/NEJMoa035060 PMID:14523142

45. Adegbola RA, Secka O, Lahai G, Lloyd-Evans N, Njie A, Usen $S$ et al. Elimination of Haemophilus influenzae type $b(\mathrm{Hib})$ disease from The Gambia after the introduction of routine immunisation with a Hib conjugate vaccine: a prospective study. Lancet 2005;366:144-50.http://dx.doi.org/10.1016/ S0140-6736(05)66788-8 PMID:16005337

46. Scott JA, English $M$. What are the implications for childhood pneumonia of successfully introducing Hib and pneumococcal vaccines in developing countries? PLoS Med 2008;5:e86.http://dx.doi.org/10.1371/journal. pmed.0050086 PMID:19226734

47. O'Meara WP, Bejon P, Mwangi TW, Okiro EA, Peshu N, Snow RW et al. Effect of a fall in malaria transmission on morbidity and mortality in Kilifi, Kenya. Lancet 2008;372:1555-62. http://dx.doi.org/10.1016/S0140-6736(08)61655-4 PMID:18984188

48. Egyir B, Guardabassi L, Sørum M, Nielsen SS, Kolekang 
A, Frimpong $E$ et al. Molecular epidemiology and antimicrobial susceptibility of clinical Staphylococcus aureus from healthcare institutions in Ghana. PLoS ONE 2014;9:e89716.http://dx.doi.org/10.1371/journal. pone.0089716 PMID:24586981

49. Beilouny B, Ciupea A, Eloy C, Simon G. Fatal communityacquired pneumonia due to Staphylococcus aureus carrying Panton-Valentine leukocidin genes after a stay in Africa. Intensive Care Med 2008;34:388-9.http://dx.doi. org/10.1007/s00134-007-0854-1 PMID:17896102

50. O'Dempsey TJ, McArdle TF, Lloyd-Evans N, Baldeh I, Laurence BE, Secka $\mathrm{O}$ et al. Importance of enteric bacteria as a cause of pneumonia, meningitis and septicemia among children in a rural community in The Gambia, West Africa. Pediatr Infect Dis J 1994;13:122-8.http://dx.doi. org/10.1097/00006454-199402000-00009 PMID:8190537

51. Berkley JA, Munywoki P, Ngama M, Kazungu S, Abwao J, Bett $A$ et al. Viral etiology of severe pneumonia among Kenyan infants and children. JAMA 2010;303:2051-7. http://dx.doi.org/10.1001/jama.2010.675 PMID:20501927

52. Gessner BD, Shindo N, Briand S. Seasonal influenza epidemiology in sub-Saharan Africa: a systematic review. Lancet Infect Dis 2011;11:223-35. http://dx.doi. org/10.1016/S1473-3099(11)70008-1 PMID:21371656

53. Weber MW, Dackour R, Usen S, Schneider G, Adegbola RA, Cane $P$ et al. The clinical spectrum of respiratory syncytial virus disease in The Gambia. Pediatr Infect Dis J 1998;17:224-30.http://dx.doi.org/10.1097/00006454199803000-00010 PMID:9535250

54. Weber MW, Mulholland EK, Greenwood BM. Respiratory syncytial virus infection in tropical and developing countries. Trop Med Int Health 1998;3:268-80.http://dx.doi. org/10.1046/j.1365-3156.1998.00213.x PMID:9623927

55. McCullers JA. Preventing and treating secondary bacterial infections with antiviral agents. Antivir Ther 2011;16:12335.http://dx.doi.org/10.3851/IMP1730 PMID:21447860

56. Madhi SA, Klugman KP; Vaccine Trialist Group. A role for Streptococcus pneumoniae in virus-associated pneumonia. Nat Med 2004;10:811-3. http://dx.doi.org/10.1038/ nm1077 PMID:15247911

57. Sun K, Metzger DW. Inhibition of pulmonary antibacterial defense by interferon-gamma during recovery from influenza infection. Nat Med 2008;14:558-64. http:// dx.doi.org/10.1038/nm1765 PMID:18438414

58. Reddy EA, Shaw AV, Crump JA. Community-acquired bloodstream infections in Africa: a systematic review and meta-analysis. Lancet Infect Dis 2010;10:417-32. http://dx.doi.org/10.1016/S1473-3099(10)70072-4 PMID:20510282

59. Brent AJ, Ahmed I, Ndiritu M, Lewa P, Ngetsa C, Lowe B et al. Incidence of clinically significant bacteraemia in children who present to hospital in Kenya: community-based observational study. Lancet 2006;367:482-8.http://dx.doi. org/10.1016/S0140-6736(06)68180-4 PMID:16473125

60. Mabey DC, Brown A, Greenwood BM. Plasmodium falciparum malaria and Salmonella infections in Gambian children. J Infect Dis 1987;155:1319-21.http://dx.doi. org/10.1093/infdis/155.6.1319 PMID:3553352

61. Williams TN, Uyoga S, Macharia A, Ndila C, McAuley CF, Opi $\mathrm{DH}$ et al. Bacteraemia in Kenyan children with sickle-cell anaemia: a retrospective cohort and case-control study. Lancet 2009;374:1364-70.http://dx.doi.org/10.1016/ S0140-6736(09)61374-X PMID:19747721

62. Cunnington AJ, de Souza JB, Walther M, Riley EM. Malaria impairs resistance to Salmonella through heme- and heme oxygenase-dependent dysfunctional granulocyte mobilization. Nat Med 2012;18:120-7.http://dx.doi. org/10.1038/nm.2601 PMID:22179318

63. Biggs HM, Lester R, Nadjm B, Mtove G, Todd JE, Kinabo GD et al. Invasive Salmonella infections in areas of high and low malaria transmission intensity in Tanzania. Clin Infect Dis 2014;58:638-47.http://dx.doi.org/10.1093/cid/cit798 PMID:24336909

64. Maclennan CA. Out of Africa: links between invasive nontyphoidal Salmonella disease, typhoid fever, and malaria. Clin Infect Dis 2014;58:648-50.http://dx.doi. org/10.1093/cid/cit803 PMID:24336912

65. Biggs HM, Bui DM, Galloway RL, Stoddard RA, Shadomy SV, Morrissey $A B$ et al. Leptospirosis among hospitalized febrile patients in northern Tanzania. Am J Trop Med Hyg 2011;85:275-81.http://dx.doi.org/10.4269/ ajtmh.2011.11-0176 PMID:21813847

66. Okiro EA, Hay SI, Gikandi PW, Sharif SK, Noor AM, Peshu $\mathrm{N}$ et al. The decline in paediatric malaria admissions on the coast of Kenya. Malar J 2007;6:151.http://dx.doi. org/10.1186/1475-2875-6-151 PMID:18005422

67. Okiro EA, Kazembe LN, Kabaria CW, Ligomeka J, Noor AM, Ali D et al. Childhood malaria admission rates to four hospitals in Malawi between 2000 and 2010. PLoS ONE 2013;8:e62214.http://dx.doi.org/10.1371/journal. pone.0062214 PMID:23638008

68. Berkley JA, Lowe BS, Mwangi I, Williams T, Bauni E, Mwarumba $S$ et al. Bacteremia among children admitted to a rural hospital in Kenya. N Engl J Med 2005;352:3947.http://dx.doi.org/10.1056/NEJMoa040275 PMID:15635111

69. Berkley JA, Ross A, Mwangi I, Osier FH, Mohammed M, Shebbe $M$ et al. Prognostic indicators of early and late death in children admitted to district hospital in Kenya: cohort study. BMJ 2003;326:361.http://dx.doi.org/10.1136/ bmj.326.7385.361 PMID:12586667

70. Alonso $\mathrm{PL}$, Lindsay SW, Armstrong Schellenberg JR, Gomez P, Hill AG, David PH et al. A malaria control trial using insecticide-treated bed nets and targeted chemoprophylaxis in a rural area of The Gambia, west Africa. 2. Mortality and morbidity from malaria in the study area. Trans R Soc Trop Med Hyg 1993;87 Suppl 2:13-7. http://dx.doi.org/10.1016/0035-9203(93)90170-U PMID:8212104 